\section{DE DE GRUYTER} OPEN
Journal of Intercultural Management Vol. 5, No. 2, June 2013, pp. 101-111

DOI 10.2478/joim-2013-0013

\author{
Michał Chmielecki \\ Społeczna Akademia Nauk
}

\title{
Culture as a barrier of knowledge sharing
}

\begin{abstract}
Management in last decades has seen knowledge sharing become a key tool for the success of a variety of institutions. Many international companies and other organizations have developed knowledge management programs as key to their future development strategies. There are number of international organizations that have identified knowledge sharing as one of their core management tools. Yet despite its growing popularity, knowledge sharing remains a complex and challenging task. This article discusses what cultural barriers can impede knowledge sharing processes.

Keywords: Knowledge sharing, Knowledge management, Corporate culture, Cultural barriers, Cultural values
\end{abstract}

\section{Introduction}

Culture plays an important role in the success of a knowledge management effort. Many examples can be found where well designed knowledge management tools and processes failed because people believed they were already sharing well enough, or that senior managers did not really support it, etc. However, no matter strong the commitment and approach to knowledge management, culture is stronger. That is why the aim of this article is to discuss how can managers and other organization member overcome cultural barriers of knowledge management.

\section{Knowledge management}

One of the most significant challenges to understanding knowledge management is the difficulty in understanding the concept of knowledge. A common approach to this subject is the positing of a hierarchical relationship between data, information, and knowledge. This approach suggests that data holds the most basic status. When processed for practical application, 
data is raised to the level of information. Information, in turn, is applied by individuals to create knowledge. "Knowledge is information possessed in the mind of individuals: it is personalized information (which may or may not be new, unique, useful, or accurate) related to facts, procedures, concepts, interpretations, ideas, observations, and judgments" [Alavi \& Leidner, 2001, p. 109].

Knowledge Management has emerged over the last decades as a result of many intellectual, societal, and business forces. Knowledge Management has become a valuable business tool. However it is a complex one, and will still be under development for a long time to come. Significant changes in the workplace have already taken place, but changes to come are expected to be greater.

\section{Knowledge sharing}

Knowledge sharing is regarded as a fundamental means through which organizational competitive advantage can be reached [Jackson et al. 2006]. The way knowledge is shared within the frameworks of the organization is essential and central not only to the success of the organization where it takes place but also among those who share it, since those who take part in the knowledge sharing process also benefit from it.

The study of knowledge sharing has emerged as a key research area from a broad and deep field of study on technology transfer and innovation, and more recently from the field of strategic management. Increasingly, knowledgesharing research has moved to an organizational learning perspective.

Knowledge sharing, it is mainly described as an activity during which information or other important contents are shared [Möller, Svahn 2004; Li 2010]. The approach presented by Bartol and Srivastava [2002] contains information as an element of knowledge sharing and defines it as the action in which relevant information are diffused by employees to others across the organization. Möller and Svahn [2004, p. 220] stress that knowledge sharing is "sharing not only codified information, such as production and product specifications, delivery and logistics information, but also management beliefs, images, experiences, and contextualized practices such as business-process development". Li [2010, p. 40] defines knowledge sharing as an activity "in which participants are involved in the joint process of contributing, negotiating and utilizing knowledge".

The literature identifies five primary contexts that can affect such successful knowledge-sharing implementations:

- the relationship between the source and the recipient,

- the form and location of the knowledge,

- the recipient's learning predisposition, the source's knowledge-sharing capability, 
- and the broader environment in which the sharing occurs.

A synthesis of this research suggests three types of knowledge-sharing activities to be evaluated:

- analyses of the form and the location of the knowledge (it is important because each can affect the types of sharing processes that will be necessary as well as how challenging these

processes might be).

- the types of agreements (rules of engagement and managerial practices adopted by the parties are important to evaluate in that they can shape both the flows of resources and knowledge between the parties and the actions taken to overcome and accommodate significant relational differences between the parties).

- the specific knowledge-sharing activities used (they are important in that they are the means through which the parties seek to facilitate knowledge sharing).

While some theorists argue that high investment rates in physical and human capital drive national innovation and growth rates [Kim \& Lau, 1994; Krugman, 1994], 'assimilation theorists' instead argue that entrepreneurship, effective learning, and innovation are separate, but equally important variables affecting development [Kim \& Nelson, 2000]. Central to both approaches, nonetheless, is an understanding of the importance of the sharing of ideas.

The study of knowledge sharing has its roots within the technology transfer and innovation literature. However it can be observed that different nations' successes or failures in fostering economic growth through technological development can be partially explained by the role of culture.

\section{Culture}

The role of culture in the world of business has been the subject of various research for at least twenty-five years. Researchers have studied the influence or the impact of national cultures on organizational behavior and the way managers from different cultural backgrounds interact with one another. [e.g. Adler, 2002; Hofstede, 1980, 1991; Trompenaars \& Hampden-Turner, 1997, Early and Erez, 1997].

Sułkowski [2002] observes that the notion of a culture is complex and it is characterizes by a great variety of definitions functioning both in theory and in practice so a given definition may express only one, selected aspect of a culture. In other words, the complexity of culture makes impossible to create one, proper definition. One of the most commonly used definitions of culture, being not a complex one at the same time, in the literature on culture, negotiations and business in general has been provided by Geert Hofstede, who was the author of the first major empirical multi-country study of consequences that culture has 
for the field of management. Hofstede and Hofstede [2005] suggest that "culture is the collective programming of the mind that distinguishes the members of one group or category of people from others" [p. 4].] Bjerke [2004] expresses the opinion that culture is a mechanism which fuses social structures [p. 13]. Thus culture is an output formed by a given community consisted of some bases, ideas and classes. Schwartz [qtd. in Lewicki et al. 2007] describes culture as the values, distinguishing ten essential values, namely: power, security, traditions, conformity, benevolence, universalism, self-directions, simulation, hedonism achievement and power [p. 237]. What is more, the values might cooperate with each other or there might be a conflict between them. In practice, the values which are on the opposite side of the circle tend to be in a conflict. For the purpose of this paper the definition given by Hofstede and Hofstede [2005] is the most appropriate for the working definition. It explains the term of the culture precisely, focusing on a culture as a tool which indicates an identity of a given group and underlines its unique character.

\section{Cultural dimensions}

The aim of this part is to describe Hofstede's five cultural dimensions that are used in order to study the cultural norms. Hofstede and Hofstede [2007] indicate that these are the values that are the vital elements of a culture thus while conducting a research on cultural dimensions it is crucial to focus on values. The dimensions of a culture allow people to compare one culture with the other [p.33-36].

Hofstede and Hofstede [2005] say in their book that "individualism stands for a society in which the ties between individuals are loose: everyone is expected to look after himself or herself and his or her immediate family only" [p. 401]. In other words, a member of an individualistic society is concentrated on his own interests and interests of his relatives. Hofstede [2005] adds that there are only few societies in the world which might be called individualistic, great majority of societies are more interested in common good than thus these societies are called collectivist [p. 74]. Hofstede and Hofstede [2005] define collectivism as "societies in which people from birth onward are integrated into strong, cohesive in-group's, which throughout people's lifetimes continue to protect them in exchange for unquestioning loyalty" [p. 76]. Thus the post important aspect which distinguishes collectivistic societies is a close bond between members of a group.

Individualistic societies focus on the idea of self-actualization while collectivistic societies put emphasis on the common objectives of the group. Individuality and individual rights tend to be the crucial values for high individual cultures. In contrast, in collectivistic cultures there is a close tie between people, they take responsibility for other members of a group, they 
protect one another in exchange for loyalty. Hofstede and Hofstede [2005] mention that there is a negative correlation between individualism and power distance, namely, a country which is long-power distance is collectivist, whilst small-power distance countries and individualist [p. 82].

Hofstede and Hofstede [2005] claim that "Power distance can be defined as the extent to which the less powerful members of institutions and organizations within a country expect and accept that power is distributed unequally" [p. 46]. Hofstede and Hofstede [2005] describe above mentioned institutions as primary layers of community, namely a family, school and workplace [p. 46]. Brown [2000] adds that power distance is able to define the range of scope to which less powerful individual approves the disparity of power within a community [p. 190]. Brown [2000] says in his book that power distance exists in every single culture yet the tolerance of this inequality varies among cultures [p. 190]. In other words, power distance indicates the degree of unequal division of power that a member of a group is able to accept. Although above mentioned division of power exists in each culture, members of given culture have different attitude toward the division thus there can distinguished high and low-power distance societies. Lebaron and Pillay [2006] observe that due to gender, race, age, education and social statues in a high-power distance culture some member's are being considered as superior to others [p. 46]. Lebaron and Pillay [2006] suggests that "high-power distance starting points shape more formal relations, while low-power distance starting points invite more open conflict and discussion between those at different levels within an organization" [p. 47]. Thus high-power distance cultures are not as flexible and low-power distance cultures insofar as building relationships.

Hofstede and Hofstede [2005] explain that "Uncertainty avoidance is the extent to which the members of a culture feel threatened by ambiguous or unknown situations" [p. 403]. In other words, uncertainty avoidance index indicates the degree to which members of a given community feel nervous in an unknown situation. Brown [2000] makes an important point that countries whose uncertainty avoidance index is weak tend to be contemplative, less aggressive and relax whilst countries with strong uncertainty avoidance seem to be more active, aggressive and intolerant [p. 190]. Hofstede and Hofstede [2005] theorize that communities with strong avoidance index tend to create vide range of laws and regulations in order to prevent uncertainty [p. 182]. They add that countries with weak avoidance index use more often common sense [Hofstede and Hofstede 2005 p.184]. To sum up, people derived from form a high uncertainty avoidance culture fully respect the law and other regulations. In contrast, a low uncertainty avoidance culture is not as rule-oriented, accepts changes and is able to risk to the challenge. 
Hofstede and Hofstede [2005] suggest that "Masculinity stands for a society in which emotional gender roles are clearly distinct: men are supposed to be assertive, tough, and focused on material success; woman are supposed to be more modest, tender, and concerned with the quality of life" [p. 402]. Thus in a masculine society there is a strongly visible division between a role which is played by a man and that played by a woman [See: Świderska ,\&\#8230;\&\#8230;]. According to Hofstede and Hofstede [2005] the contrary of masculine society is feminine one which is defined as society where men's and women's roles dovetail [p. 120]. They claim in their book that masculine and feminine societies vary in solving global conflicts, namely feminine countries aim to negotiations and consensus whilst masculine societies achieve their gorals by fight [Hofstede and Hofstede 2005 p.150].

Hofstede and Hofstede [2005] define the term long- term orientation as "The fostering of virtues oriented towards future rewards, in particular perseverance and thrift" [p. 401]. As far as the short term orientation is concerned, Hofstede and Hofstede [2005] claim that the short term orientations is "The fostering of virtues related to the past and present- in particular, respect for tradition, preservation of 'face', and fulfilling social obligations" [p. 401]. They mention that the opposite of long-term orientation is short-term orientation where people respect the tradition and their main aims is past and present [Hofstede and Hofstede 2005 p. 210]. In other words, long-term orientated countries accept changes with ease whilst countries which have short term orientation are more conventional and traditional. Taking Hofstede's and Hofstede's [2005] view of the situation key features of short term orientation are as follows: veneration of tradition, involvement in personal stability, social status and obligations, actions which will produce immediate results [p. 210]. They remark that perseverance as a tool which will bring slow results, veneration of circumstances and forethought are the key features of long-term orientation [Hofstede and Hofstede 2005 p. 210]. To conclude, the crucial value of a long-term orientation culture is long-lasting commitment whilst short-term orientation culture is more flexible thus changes occur more frequently and rapidly. People derived from long-term orientation culture tend to accept slow results and are more persistent to achieve their aims.

\section{Knowledge sharing and culture}

Knowledge sharing efforts often are seen to encounter difficulties from culture. [DeLong \& Fahey, 2000; O’Dell \& Grayson, 1998].

Ernst and Young conducted a study that identified culture as the biggest impediment to knowledge transfer, citing the inability to change people's behaviors as the biggest hindrance to managing knowledge [Watson, 1998]. Another study of 453 firms, showed that over half of the companies indicated 
that organizational culture was a major barrier to success in their knowledge management initiatives [Ruggles, 1998].

Studies on the role of culture in knowledge management have focused on such issues as the effects of organizational culture on knowledge sharing behaviours [DeLong \& Fahey, 2000] and the influence of culture on the capabilities provided by knowledge management [Gold, Malhotra \& Segars, 2001] as well as on the success of the knowledge management initiative [Baltahazard \& Cooke, 2003].

Culture influences knowledge sharing behaviors in four main ways:

a) culture heavily influences what is perceived as useful, important or valid knowledge in an organization;

b) culture mediates the relationship between levels of knowledge, i.e., it dictates what belongs to the organization and what knowledge remains in control of the individual employee, determining who is expected to control specific knowledge as well as who must share it and who can hoard it;

c) culture creates a subtext for social interaction in that it represents the rules and practices that determine the environment within which people communicate

d) culture shapes the creation and adoption of new knowledge [DeLong, \& Fahey, 2004].

Organizational culture determines the social context which determines "who is expected to control what knowledge, as well as who must share it, and who can hoard it" [Delong \& Fahey,2000, p. 118]. Consulting firms such as KPMG report that a major aspect of knowledge management initiatives involves working to shape organizational cultures that hinder their knowledge management programs [KPMG, 1998]. Numerous research findings [e.g. Hasan \& Gould, 2001; Schultze \& Boland, 2000] help to demonstrate the profound impact that culture may have on knowledge management and sharing practices and of the crucial role of senior management in fostering cultures conducive to these practices [Brown \& Duguid, 2000; Davenport, DeLong, \& Beers, 1998; DeLong \& Fahey, 2000; Gupta \& Govindarajan, 2000; Hargadon, 1998; KPMG, 1998; von Krogh, 1998].

Culture affects the level of collaboration within an organization [Grandys, Grandys, 2011] and it is collaboration that is the key to successful knowledge sharing. Ardichvili et al. [2006] discussed cross-cultural differences in knowledge sharing patterns which were based on three criteria: individualism versus collectivism, in-group versus out-group orientation, and fear of losing face. Individualism is the tendency of people to place their personal goals ahead of the goals of the organization, while individuals from collectivist cultures tend to give priority to the goals of the larger collective, group or company to which they belong. Collectivists tend to distinguish sharply between 
in-group and out-group members. Chow, Deng and Ho [2000] researched factors influencing knowledge sharing behaviors and found that e.g. Chinese nationals were much more reluctant to share with an out-group member than employees in the United States were. Hwang, Francesco, Kessler [2003] found that individualists were more concerned with gaining face (i.e. impressing colleagues) than collectivists. They also found that individuals who want to gain face were more likely to use formal communications channels to show their knowledge and ability, while those who feared losing face preferred more informal communication channels.

Sveiby and Simmons [2002] believe that the collaborative climate was one of the major factors influencing the effectiveness of knowledge programs as it improved knowledge sharing and organizational effectiveness. It was suggested that a culture audit should take place to determine the extent to which organizational culture exhibited the cultural values of collaboration, empowerment, action taking and informality [Albert, \& Picq, 2004].

Baltahazard and Cooke [2003] ascertained that constructive cultures ${ }^{1}$ tended to achieve greater knowledge management success. Similarly, Gold, et al. [2001] found that more supportive, encouraging organizational cultures positively influence knowledge management infrastructure capability and resulting knowledge management practice. Finally, Jarvenpaa and Staples [2001] determined that organizational cultures rating high in solidarity will result in a perception of knowledge as being owned by the organization.

Some companies might be tempted to reward knowledge sharing behavior in order strenghten successful collaboration and teaming. Albert and Picq [2004] asserted that most companies do not provide individual rewards based solely on the ability to learn or to share knowledge. Hutchings and Michailova [2004] recommended that the group, rather than the individual, should be rewarded. Bock and Kim [2002] found no relationship between the use of rewards and knowledge sharing. Instead, they concluded that promoting a positive attitude towards knowledge sharing caused a positive intention to share knowledge.

\section{Summary}

In the Knowledge Economy, knowledge is the most valuable asset and the only source of sustainable competitive advantage. Increasingly, what organizations know determines the degree of business success. Many organizational factors, such as hierarchy, power, available resources, support, reward systems and, ultimately, culture could either impede or promote knowledge sharing behaviors. This study has demonstrated that there are myriad cultural barriers to knowledge sharing. They can often prevent effective knowledge sharing.

1 Cultures emphasizing values related to achievement, affiliation, and self-actualization, encouragement. 
It is therefore necessary to identify and try to understand them in order to eliminate their influence. Influence of some of them is possible to be removed some of them will still remain.

\section{Bibliography}

Adler,N. J., International dimensions of organizational behavior[4th ed.]. Cincinnati, $\mathrm{OH}$ :Thomson/South-Western, 2002

Alavi M., Leidner, D. (2001). Knowledge Management and Knowledge Management Systems: Conceptual Foundation and An Agenda for Research, MIS Quarterly, 25(1)

Alavi, M., Kayworth, T., \& Leidner, D. (2005). Organizational and sub-unit values in the process of knowledge management (Working Paper). Baylor University.

Albert, M., \& Picq, T. (2004). Knowledge-based organizations: Perspectives from San Francisco Bay area companies. European Journal of Innovation Management, 7(3), 169-177.

Baltahazard, P. A., \& Cooke, R. A. (2003). Organizational culture and knowledge management success: Assessing the behavior-performance continuum (Working Paper). Arizona State University West.

Bartol, K.M. and Srivastava, A. (2002) "Encouraging Knowledge Sharing: The Role of Organizational Reward Systems”, Journal of Leadership and Organizational Studies, Vol 9, No 1

Bjerke B., Kultura a style przywództwa zarządzanie w warunkach globalizacji, Oficyna Ekonomiczna, Kraków 2004.

Bock, G. W., \& Kim, Y. G. (2002). Breaking the myths of rewards: An exploratory study of attitudes about knowledge sharing. Information Resource

Management Journal, 15(2)

Brown H.D., Rodgers T.S., Doing second language research, Oxford University Press, Oxford 2000.

Brown, S. J., \& Duguid, P. (2000). Balancing act: How to capture knowledge without killing it. Harvard Business Review, 78(3), 73-80.

Deluga W., Wallis A., Wpływ różnic kulturowych na marketing i zarządzanie, in Sułkowski Ł., Waniek K., (eds.), Studia z zarządzania międzykulturowego Cz. II, SWSPiZ, Łódź 2009.

Glińska-NeweśA., Kulturowe uwarunkowania zarządzania wiedzą w przedsiębiorstwie, Towarzystwo Naukowej Organizacji i Zarządzania, Stowarzyszenie Wyższej Użyteczności „Dom Organizatora”, Toruń 2007.

Davenport, T. H., De Long, D. W., \& Beers, M. C. (1998). Successful knowledge management. Sloan Management Review, 39(2), 43-57.

DeLong, D. W., \& Fahey, L. (2000). Diagnosing cultural barriers to knowledge management. Academy of Management Executive, 14(4), 113-127. 
Earley, P., Erez, M. The transplanted executive: Why you need to understand how workers in other countries see the world. Oxford, UK: Oxford University Press, 1997

Gold, A. H., Malhotra, A., \& Segars, A. H. (2001). Knowledge management: An organizational capabilities perspective. Journal of Management Information Systems, 18(1), 185-214.

Grandys E., Grandys A., Transnational corporations and cross cultural managament, OiK, Nr 5 (148), 2011

Gupta, A. K., \& Govindarajan, V. (2000). Knowledge management's social dimension:

Lessons from Nucor Steel. Sloan Management Review, 42(1), 71-80.

Hansen, M. T., Nohria, N., \& Tierney, T. (1999). What's your strategy for managing knowledge? Harvard Business, Review, 77(2), 106-115.

Hasan, H., \& Gould, E. (2001). Support for the sense-making activity of managers.

Decision Support Systems, Copyright (c) 2006, Idea Group Inc. Copying or distributing in print or electronic forms without written permission of Idea Group Inc. is prohibited. International Journal of e-Collaboration, 2(1), 17-40, January-March 200639 31(1), 71-86.

Hofstede, G., Culture's consequences. Beverly Hills,CA:Sage, 1980.

Hofstede, G., Cultures and Organizations: Software of the Mind. London: McGrawHill, 1991.

Hofstede G., Hofstede G.J., Cultures and Organizations Software of the Mind, McGraw Hill, New York 2005.

Hofstede G., Hofstede G.J., Kultury i Organizacje, Polskie Wydawnictwo Ekonmiczne, Warszawa 2007.

Humes S., Managing the Multinational, Prentice Hall, Hertfordshire 1993.

Hutchings, K., \& Michailova, S. (2004). Facilitating knowledge sharing in Russian and Chinese subsidiaries: The role of personal networks and group membership. Journal of Knowledge Management, 8(2)

Jandt F.E., An introduction to intercultural communication, identities in a global community, SAGE, the USA, 2006.

Jarvenpaa, S. L., \& Staples, S. D. (2001). Exploring perceptions of organizational ownership of information and expertise. Journal of Management Information

KPMG Management Consulting. (1998). Knowledge management: Research report.

Lebaron M., Pillay V., Conflict across cultures A unique Experience of Bridging Differences, Intercultural Press, The USA 2006.

Lewicki J.R., Saunders D.M., Barry B., Minton J.W., Zasady negocjacji kompendium wiedzy dla trenerów i menadżerów, Rebis, Poznań 2005.

Lewicki R.J., Barry B., Saunders D.M., Essentials of negotiations, McGraw Hill, New York 2007. 
Li, W. (2010) "Virtual Knowledge Sharing in a Cross-cultural Context", Journal of Knowledge Management, Vol 14, No 1

Mikułowski-Pomorski J., Jak narody porozumiewają się ze sobą w komunikacji międzynarodowej i komunikowaniu medialnym, Universitas, Kraków 2007.

Möller, K. and Svahn, S. (2004) "Crossing East-West Boundaries: Knowledge Sharing in Intercultural Business Networks", Industrial Marketing Management, Vol 33, No 3, pp. 219-228

Rastogi, P.N. , Knowledge Management and Intellectual Capital - The New Virtuous Reality of Competitiveness. Human Systems Management, 19(1), 2000.

Ruggles, R., The state of the notion: Knowledge management in practice. California Management Review 40(3), 1998.

Schultze, U., Boland, R., Knowledge management technology and the reproduction of knowledge work practices. Journal of Strategic Information Systems, 9(2-3), 2000.

Sitko-Lutek A., Wpływ znajomości kulturowych uwarunkowań doskonalenia menedżerów na skuteczność procesów organizacyjnego uczenia się, [w:] Instrumenty i formy organizacyjne procesów zarządzania w społeczeństwie informacyjnym, Tom 2, red. A. Stabryła, Wydawnictwo Akademii Ekonomicznej w Krakowie, Kraków 2004.

Stor, M., Kulturowa interpretacja problemów kadrowo-organizacyjnych w korporacjach międzynarodowych w Polsce - wyniki badań empirycznych, [w:] Koncepcje zarządzania kapitałem ludzkim we współczesnych organizacjach, red. J. Stankiewicz, Uniwersytet Zielonogórski, Zielona Góra 2008.

Sveiby, K. E., \& Simons, R. (2002). Collaborative climate and effectiveness of knowledge work. Journal of Knowledge Management, 6(5), 420-433.

Sułkowski, Ł. 2002. Procesy kulturowe w organizacjach. Koncepcja, badania i typologia kultur organizacyjnych, Torun-Łódź, Towarzystwo Nauk Organizacji i Kierowania - Dom Organizatora.

Trompenaars, F., Hampden-Turner,C., Riding the waves of culture (2nd ed.). London: Nicholas Brealey, 1997

von Krogh, G. (1998). Care in knowledge creation. California Management Review, 40(3), 133-153. Systems, 18(1), 151-183.

Watson, S., Getting to "aha!" companies use intranets to turn information and experience into knowledge - And gain a competitive edge. Computer World, 32(4), 1998. 